\title{
PEMANFAATAN TEKNOLOGI AUGMENTED REALITY SEBAGAI MEDIA PENGENALAN SEJARAH GEREJA BLENDUK SEMARANG
}

\author{
Noor Hasyim ${ }^{1}$, Ali Muqoddas ${ }^{2}$ \\ 1,2Desain Komunikasi Visual, Fakultas Ilmu Komputer, Universitas Dian Nuswantoro \\ Jl. Imam Bonjol 207 Pendrikan Kidul, Semarang -Jawa Tengah \\ 1hasyim.nahl@gmail.com, 2ali.muqoddas@gmail.com
}

\begin{abstract}
Abstrak : Gereja Blenduk merupakan bangunan yang menjadi salah satu ikon dari Kota Semarang. Gereja Blenduk yang berada di kawasan Kota Lama semarang ini juga menjadi salah satu destinasi wisata unggulan dari Kota Semarang. Berbagai upaya revitalisasi dan edukasi dilakukan untuk menjaga kelestarian bangunan Gereja Blenduk. Namun pengetahuan masyarakat tentang sejarah Bangunan Gereja Blenduk masih kurang. Pemanfaatan teknologi berbasis augmented reality dapat menjadi alternatif solusi untuk mengenalkan sejarah bangunan Gereja Blenduk. Penelitian ini menggunakan metode kualitatif dengan metode pengumpulan data berupa observasi, wawancara, dokumentasi dan studi pustaka. Dalam pengembangan aplikasi augmented reality tentang Gereja Blenduk digunakan model waterfall dari Winston W. Royce yang terdiri dari analysis, design, implementation, testing dan maintenance. Dengan pemanfaatan teknologi digital berbasis augmented reality ini diharapkan masyarakat terutama generasi milenial lebih tertarik sehingga dapat meningkatkan pengetahuan tentang sejarah Gereja Blenduk Semarang.
\end{abstract}

Kata kunci : augmented reality, destinasi wisata, Gereja Blenduk, Sejarah, Semarang,

\begin{abstract}
Abstrac: Blenduk Church has become one of the icons of Semarang City. Blenduk Church that located in the Old Town area of Semarang is also one of the leading tourist destinations of the City of Semarang. Various revitalization and education efforts have been carried out to preserve the Blenduk Church building. But public knowledge about the history of the Blenduk Church Building is still lacking. The use of technology based on augmented reality can be an alternative solution to introduce the history of the Blenduk Church building. This study uses qualitative methods with data collection methods in the form of observation, interviews, documentation and literature study. In developing the application of agmented reality about Blenduk Church, the waterfall model of Winston W. Royce was used which consisted of analysis, design, implementation, testing and maintenance. With the use of digital technology based on augmented reality it is expected that the public, especially millennial generation, will be more interested so that they can increase knowledge about the history of Blenduk Church in Semarang City.
\end{abstract}

Keywords: augmented reality, Gereja Blenduk, history, Semarang, tourist destinations 


\section{PENDAHULUAN}

Pariwisata sering menjadi sektor utama bagi Negara-negara untuk mendorong dan memperkuat perekonomian termasuk Indonesia. Pariwisata selain dapat menambah devisa negara, juga dapat memperluas lapangan pekerjaan, serta mempromosikan budaya yang ada di Indonesia. Pendapatan sektor pariwisata di Indonesia tercatat dari tahun 2015 sampai 2018 mengalami kenaikan. Tahun 2015 pendapatan sektor pariwisata adalah 12,23 milyar Dolar Amerika sedangkan tahun 2018 tercatat pendapatan sektor pariwisata adalah 19,29 milyar Dolar Amerika(Badan Pusat Statistik, 2019). Di tahun 2018 sektor pariwisata Indonesia tercatat dengan pertumbuhan tertinggi peringkat ke-9 di dunia, versi The World Travel \& Tourism Council(Gewati, 2019).

Semarang sebagai ibu kota Jawa Tengah memiliki berbagai potensi pariwisata. Kota Semarang merupakan kota multikultural yang terdiri dari berbagai macam etnis seperti Tionghoa, Arab, Jawa dan juga Belanda. Dari berbagai etnik tersebut dihasilkan bererapa bangunan ikonik Kota Semarang yang juga merupakan destinasi wisata yang ditawarkan di Kota Semarang. Salah satu tempat wisata yang berada di Kota Semarang yang terlihat multikultural adalah Kawasan Kota Lama Semarang. Salah satu bagunan ikonik yang ada di Kawasan Kota Lama Semarang adalah banguan Gereja Blenduk semarang. Gereja Blenduk merupakan peninggalan Belanda yang menjadi tujuan utama para wisatawan saat mengunjungi Kawasan Kota Lama Semarang.

Berasarkan survei dengan menyebarkan kuesioner kepada 110 responden, sebagian besar menyatakan bahwa promosi dan media informasi untuk mengenalkan sejarah Kawasan Kota Lama Semarang masih belum maksimal. Hal tersebut juga dikatakan oleh beberapa wisatawan yang berkunjung ke Kawasan Kota Lama Semarang. Padahal dalam hal ini, penting bagi masyarakat untuk tahu dan mengenal sejarah Kawasan Kota Lama Semarang. Sebanyak 14 responden 
mengetahu, 85 responden belum mengetahui, sedangkan 11 responden belum pernah berkunjung. Sehingga dapat diambil kesimpulan sebesar $77 \%$ responden belum mengetahui sejarah bangunan di kawasan Kota Lama Semarang termasuk Gereja Blenduk Semarang.

Oleh karena itu diperlukan diperlukan sebuah media untuk mengenalkan sejarah Gereja Blenduk semarang. Era teknologi memberikan peluang dalam menyampaikan sejarah makin mudah dengan ditemukannya beberapa penemuan alat dan juga media yang memungkinkan menggabungkan antara visual, audio dan bahkan pengalaman pengguna dalam menikmati suguhan multimedia. Salah satu perkembangan multimedia saat ini adalah teknologi augmented reality. Augmented reality menjadi alternatif media untuk mengenalkan sejarah banguna Gereja Blenduk di Kawasan Kota Lama Semarang.

\section{TINJAUAN PUSTAKA}

\section{Gereja Blenduk}

Dari aspek ontologi, pariwisata dapat dijelaskan ke dalam tiga unsur yaitu pergerakan wisatawan, aktifitas masyarakat yang memfasilitasi wisatawan, dan akibat terhadapat masyarakat secara luas(Utama \& SE, 2015). Menurut Medlik (dalam Utama, 2017) ada empat aspek yang perlu diperhatikan dalam pariwisata yaitu daya tarik (attraction), transportasi (accesability), fasilitas (amenities) dan kelembagaan (ancillary). Daya tarik merupakan hal utama yang ditawarkan pariwisata. Daya tarik bisa berupa alam maupun masyarakat dan budayanya. Disamping daya tarik, pariwisata harus memperhatikan transportasi agar pengunjung mencapai tempat wisata. Fasilitas lain berupa akomodasi, restoran, pusat oleh-oleh juga harus diperhatikan. Adapun kelembagaan adalah penyelenggara perjalanan wisata seperti pemandu wisata, biro perjalanan 
pemesanan tiket dan informasi. Keempat elemen tersebut digunakan sebagai komoditas yang dikonsumsioleh wisatawan dalam satu kesatuan pariwisata.

Kawasan Kota Lama Semarang merupakan kawasan bersejarah yang pembangunannya dimulai sekitar abad ke-17. Kawasan Kota Lama ini dikenal sebagai Little Netherland karena dibangun menyerupai kota di Belanda untuk mengingatkan kembali orang Belanda di Indonesia dulu mengenai kampung halaman mereka(Kusumawanto \& Astuti, 2018). Sebagai pusat kegiatan, dibangun pula gereja yang megah yang dikenal sebagai Gereja Blenduk. Gereja Blenduk terletak di Jl. Letjen Suprapto 32 Semarang. Kubah Gereja Blenduk memiliki kemiripan dengan Gereja St. Pieter di Vatikan. Gereja Blenduk menjadi salah satu ikon dari Kota Semarang. Gereja Blenduk tercatat pula sebagai bangunan cagar budaya Kota Semarang. Gereja Blenduk juga merupakan salah satu gereja tertua di Jawa Tengah(Marzuki, 2017). Saat ini, Gereja Blenduk masih digunakan untuk ibadah dan digunakan sebagai tempat wisata rohani yang ada di Kawasan Kota Lama Semarang.

Gereja Blenduk terletak di Jl. Letjen Suprapto 32 Semarang. Gereja blenduk sangat dekat dengan Stasiun Tawang. Stasiun Tawang dan Gereja Blenduk samasama merupakan bangunan bersejarah yang berada di Kawasan Kota Lama Semarang. Karena letaknya yang dekat dengan stasiun utama Kota Semarang tersebut, akses untuk menuju Gereja Blenduk sangat mudah. Wisatawan dapat berjalan kaki sekitar 500 meter dari Stasiun Tawang untuk menuju ke Gereja Blenduk. Di samping Gereja Blenduk terdapat Taman Srigunting yang dapat dimanfaatkan wisatawan untuk beristirahat. Di dekat Geraja Blunduk juga disediakan Gedung penjulan benda-benda antik yang disebut dengan Pasar Klitikan. Penataan kawasan Gereja Blenduk dan sekitarnya ini dilakukan oleh Badan Pengelola Kawasan Kota Lama (BPK2L). 

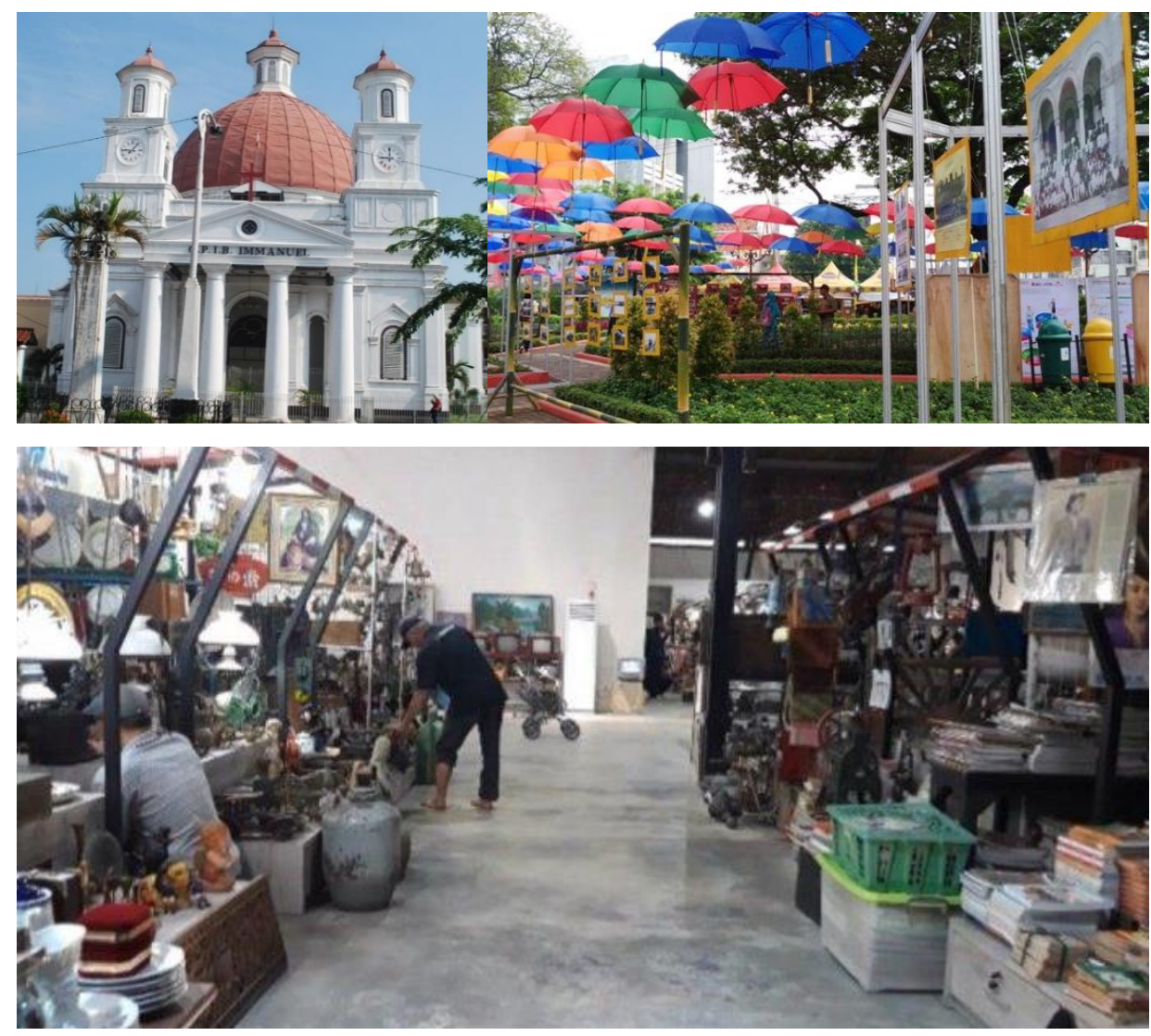

Gambar 1 Gereja Blenduk, Taman Srigunting dan Pasar Klitikan

Sumber: Tribunjateng.com

\section{Interaksi Manusia Komputer}

Pada sistem komputer, terdapat beberapa prinsip yaitu adanya masukan data dari pengguna, proses data yang dilakuan oleh komputer dan luaran melalui perangkat output(Santoso, 2009). Interaksi manusia komputer bisa diartikan sebagai rangkaian proses yang meliputi perancangan, evaluasi, dan implementasi sistem komputer yang dilakukan oleh manusia untuk berinteraksi dengan komputer yang keduanya saling memberikan masukan dan umpan balik melalui sebuah antar muka untuk memperoleh hasil akhir yang diharapkan(Mufti, 2015).

Interaksi manusia komputer membahas tentang komunikasi dan interaksi antara pengguna sistem dengan komputer agar hasil yang diperoleh sesuai dengan 
harapan pengguna. Tujuan utama dari interaksi manusia komputer adalah menciptakan sistem komputer yang efektif, aman, nyaman, dan efisian saat digunakan oleh pengguna(Martono, 2011). Proses kerja interaksi manusia komputer bisa dilihat melaui gambar sebagai berikut :

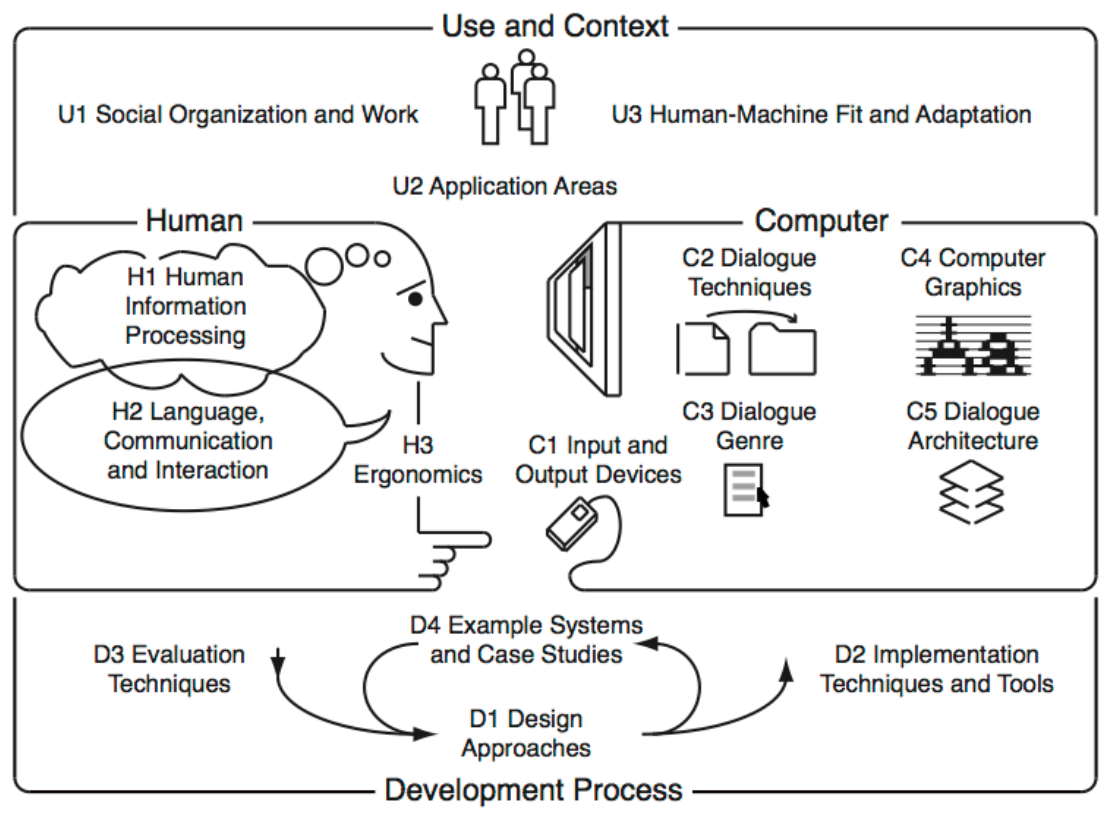

Gambar 2 Proses kerja interaksi manusia komputer Sumber: (Lamas \& Pender, 2013)

\section{Augmented reality}

Penggunaan teknologi komputer mengalami perkembangan yang sangat pesat. Teknologi augmented reality merupakan salah satu jenis interaksi manusia komputer yang baru dan memiliki perkembangan pesat. Menurut Azuma Augmented reality (AR) adalah sistem yang memiliki beberapa karakteristik yaitu menggabungkan lingkungan nyata dan virtual, berjalan secara interaktif dalam waktu nyata, dan adanya integrasi dalam tiga dimensi(Azuma, 1997). Augmented reality (AR) merupakan salah satu bagian dari Virtual Environment (VE) yang dapat memberikan gambaran kepada pengguna tentang penggabungan dunia nyata 
dengan dunia maya dilihat dari tempat yang sama. AR memiliki tiga karakteristik yaitu kombinasi dunia nyata dan virtual, interaksi secara real time, dan berbentuk 3 dimensi(Martono, 2011).

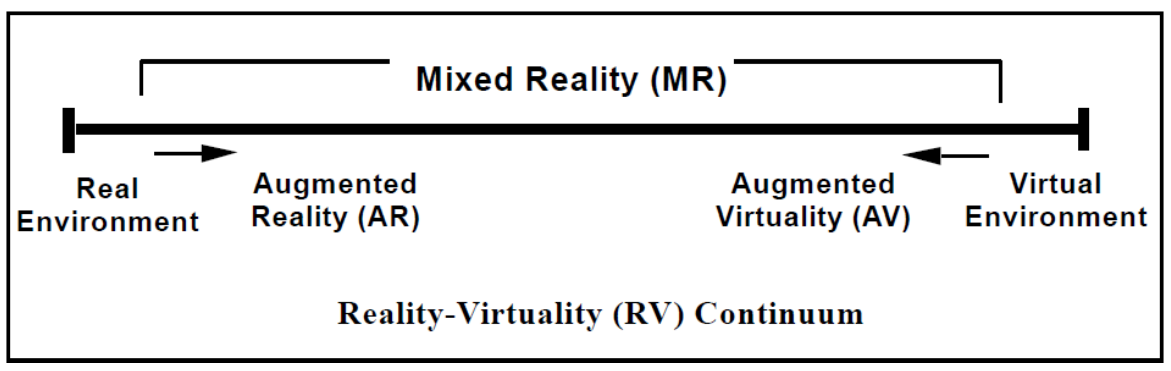

Gambar 3 Ilustrasi teknologi augmented reality

Sumber: (Speicher, Zenner, \& Degraen, 2018)

Ada dua metode yang saat ini digunakan dalam pembuatan perangkat teknologi augmented reality yaitu dengan menggunakan pola atau disebut Marker Based Tracking dan yang tanpa menggunakan pola atau Markless AR(Haryani \& Triyono, 2017). Pada Marker Based Tracking, pemunjulan obyek virtual dalam bentuk 3D dibantu dengan pola tertentu. Pola harus unik sehingga satu pola akan menampilkan obyek virtual yang lain dengan pola yang lainnya. Sedangkan pada Markless AR, pengguna tidak perlu membutuhkan pola tertentu untuk memunculkan obyek virtual sehingga kesan penyatuan obyek virtual dengan dunia nyata menjadi lebih jelas.

\section{METODE PENELITIAN}

Dalam pembuatan media berbasis augmented reality untuk mengenalkan sejarah bangunan Gereja Blenduk ini digunakan metode kualitatif dengan metode pengumpulan data berupa observasi langsung ke obyek penelitian, wawancara dan dokumetasi. Observasi dilakukan di kawasan Kota Lama Semarang dan area bangunan Gereja Blenduk. Wawancara dilakukan kepada Badan Pengelola Kawasan Kota Lama (BPK2L) yang diwakili oleh Tjahjono Raharjo selaku anggota 
BPK2L. Wawancara dilakukan untuk mendapatkan informasi terkait mengenai Gereja Blenduk. Wawancara juga dilakukan kepada beberapa pengunjung di area Gereja Blenduk untuk memperoleh data tentang pengetahuan masyarakat terhadap Gereja Blenduk serta kebutuhan masyarakat untuk membuat konsep media augmented reality. Dari dokumentasi, didapatkan beberapa media penunjang kegiatan dan wisata Gereja Blenduk seperti brosur dan panduan wisata.

Teknologi augmented reality untuk mengenalkan sejarah bangunan Gereja Blenduk ini merupakan Marker Based Tracking sehingga dibuat pula sebuah pola untuk memunculkan obyek 3D yang merupakan bangunan Gereja Blenduk Semarang. Model yang digunakan untuk mengembangkan aplikasi adalah model waterfall yang diprakarsai oleh Winston W. Royce. Model waterfall terdiri dari analysis, design, implementation, testing dan maintenance(Haryani \& Triyono, 2017).

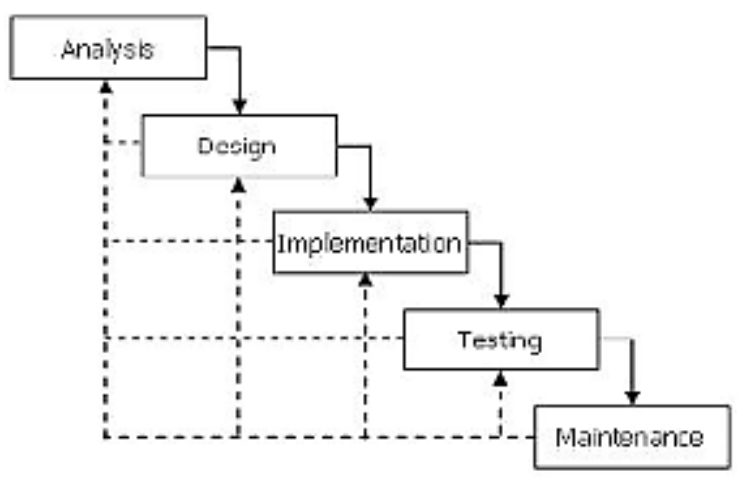

Gambar 4 Model pengembangan waterfall Winston W. Royce Sumber:(Haryani \& Triyono, 2017)

\section{HASIL DAN DISKUSI}

Dari hasil pengumpulan data berupa observasi, wawancara, dokumentasi dan studi pustaka, dibuat konsep aplikasi augmented reality untuk mengenalkan 
bangunan sejarah Gereja Blenduk kepada masyarakat. Aplikasi ini juga menjadi media promosi pariwisata Gereja Blenduk yang menjadi ikon Kawasan Kota Lama Semarang. Sebelum mendesain tampilan aplikasi augmented reality, terlebih dulu dirancang flowchart aplikasi. Flowchart dibuat sebagai panduan bagaimana aplikasi augmented reality yang dirancang berjalan dengan semestinya.

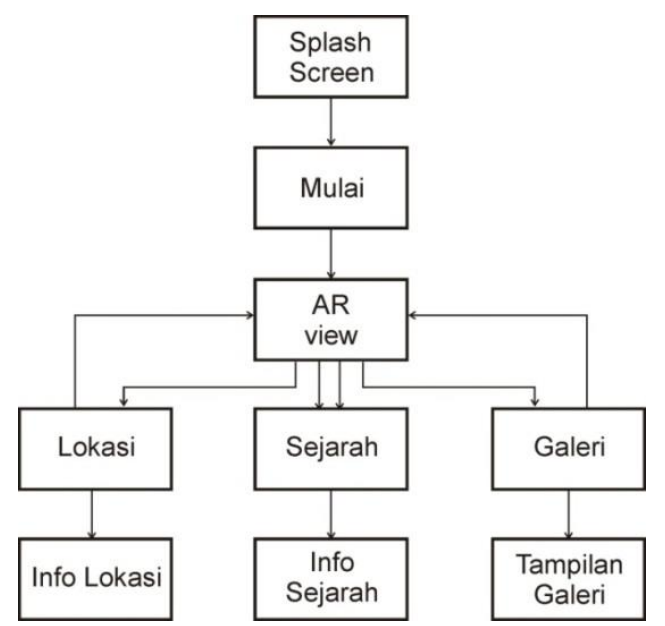

Gambar 5 Flowchart aplikasi augmented reality pengenalan Gereja Blenduk.

Sumber : penulis

Aplikasi augmented reality yang dibuat merupakan Marker Based Tracking sehingga membutuhkan pola tertentu (marker) untuk memunculkan obyek virtual dalam bentuk 3D yang diinginkan. Untuk aplikasi augmented reality Gereja Blenduk ini, marker dibuat dalam bentuk 2D dengan memanfaatkan foto asli dari Gereja Blenduk. Dari marker ini dikembangkan desain leaflet yang bisa digunakan sebagai media promosi untuk disebarkan kepada masyarakat. Leaflet tersebut mencantumkan beberapa informasi antara lain logo BPK2L sebagai badan yang mengelola Gereja Blenduk, visualisasi Gereja Blenduk, keterangan tentang leaflet sebagai media marker augmented reality serta $Q R$ code untuk mengunduh dan menginstall aplikasi melalui Google Play. Berikut desain marker dan leaflet aplikasi augmented reality pengenalan sejarah Gereja Blenduk. 

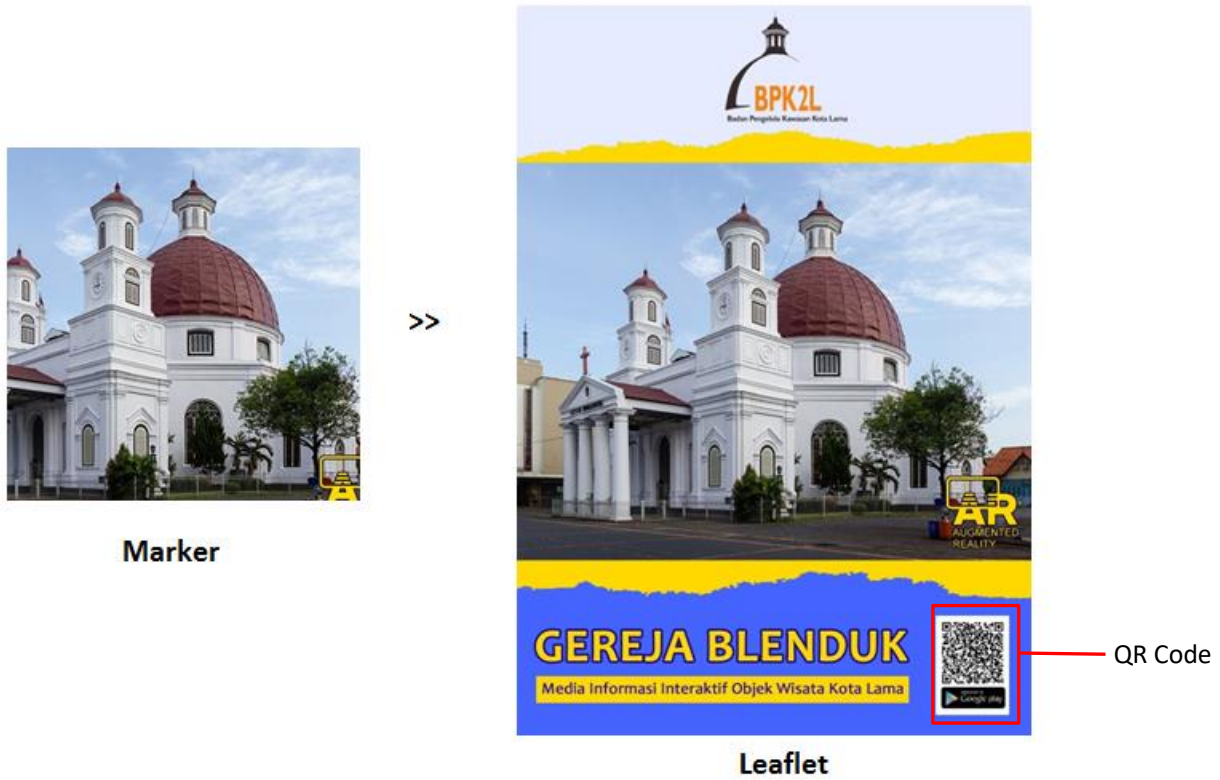

Gambar 6 Marker aplikasi augmented reality dan leaflet

Sumber : penulis

Apabila aplikasi sudah diinstall, pengguna langsung dapat mengarahkan kamara smartphone pada leaflet untuk memunculkan Gereja Blenduk dalam bentuk virtual. Gereja Blenduk virtual ini juga menjadi tombol utama untuk menunjukkan beberapa menu yaitu sejarah, lokasi dan galeri foto. Masing-masing menu dapat digunakan untuk menuju informasi seputar Gereja Blenduk. Menu sejarah digunakan untuk memberikan informasi tentang sejarah bagunan Gereja Blenduk Semarang. Menu lokasi digunakan untuk memberikan informasi tentang lokasi Gereja Blenduk kepada wisatawan yang ingin berkunjung. Untuk menghilangkan menu tersebut, user dapat mengklik kembali tampilan Gereja Blenduk virtual. Berikut beberapa interface dari aplikasi augmented reality tentang pengenalan sejarah Gereja Blenduk Semarang : 

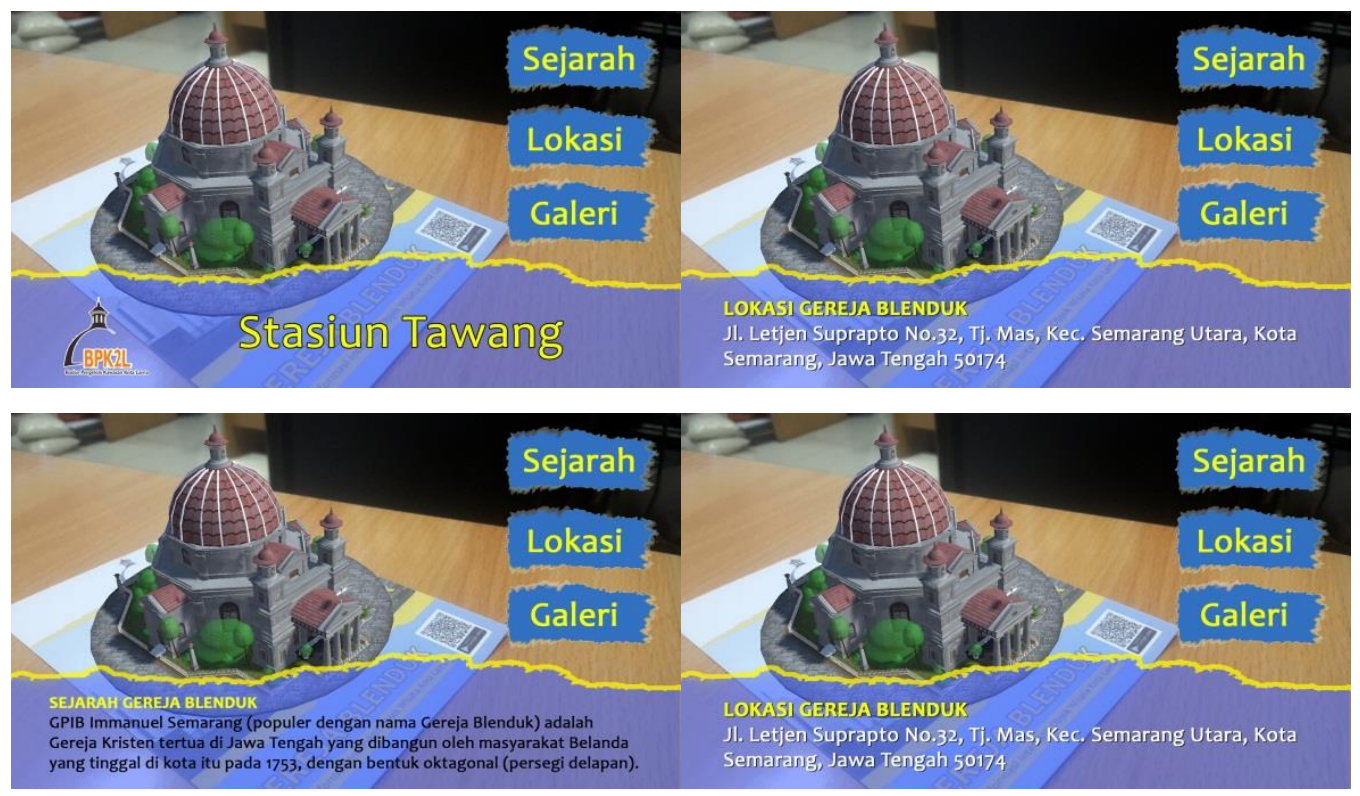

Gambar 7 Beberapa tampilan aplikasi augmented reality Gereja Blenduk

Sumber : penulis

\section{KESIMPULAN}

Pariwisata merupakan sektor penting bagi Negara karena menjadi salah satu penyokong terbesar bagi devisa. Pariwisata juga mempu menjadi media pemersatu dan meningkatkan rasa bangga terhadab tanah air. Semarang sebagai kota yang multikultural memiliki berbagai macam potensi pariwisata untuk dikembangkan. Salah satunya adalah bangunan bersejarah Gereja Blenduk yang menjadi ikon kawasan Kota Lama sekaligus ikon Kota Semarang.

\section{Melalui Badan Pengelola Kawasan Kota Lama (BPK2L) Semarang,} pemerintah Kota Semarang selalu memberikan pelayanan untuk meningkatkan pariwisata Gereja Blenduk Semarang. Pemerintah Kota juga Semarang selalu melakukan pemugaran pada beberapa bagian bangunan Gereja Blenduk. Selain bangunannya BPK2L juga berupaya memberikan edukasi kepada masyarakat tentang sejarah Gereja Blenduk namun media-media yang dibuat masih belum 
dapat menarik masyarakat sehingga pengetahuan masyarakat tentang Gereja Blenduk masih kurang.

Perancangan aplikasi augmented reality ini bertujuan untuk memberikan alternatif media untuk mengenalkan sejarah Gereja Blenduk yang menjadi salah satu ikon bagi Kota Semarang. Aplikasi ini juga dimanfaatkan untuk media promosi bagi pariwisata Kota Semarang. Dengan pemanfaatan teknologi digital berbasis augmented reality ini diharapkan masyarakat terutama generasi milenial lebih tertarik sehingga dapat meningkatkan pengetahuan tentang sejarah Gereja Blenduk Semarang

\section{PERNYATAAN PENGHARGAAN}

Ucapan terima kasih dan penghargaan yang tinggi diberikan kepada segenap civitas akademik program studi Desain Komunikasi Visual Universitas Dian Nuswantoro, baik dosen maupun mahasiswa yang telah bersedia memberikan dukungan terciptanya aplikasi augmented reality tentang Gereja Blenduk Semarang ini. Ucapan terima kasih juga diberikan kepada Badan Pengelola Kawasan Kota Lama (BPK2L) Semarang yang telah memberikan data tentang Gereja Blenduk. Penghargaan yang tinggi juga disampaikan kepada Glugu Creative Studio atas kerja samanya dalam menyediakan alat dan tempat serta pengetahuan untuk pembuatan aplikasi augmented reality.

\section{DAFTAR PUSTAKA}

Azuma, R. T. (1997). A survey of augmented reality. Presence: Teleoperators \& Virtual Environments, 6(4), 355-385.

Badan Pusat Statistik. (2019). Jumlah Devisa Sektor Pariwisata, 2015-2018. Retrieved September 12, 2019, from https://www.bps.go.id/dynamictable/2018/05/22/1357/jumlah-devisasektor-pariwisata-2015-2018.ht

Gewati, M. (2019). Bl: Industri Pariwisata Jadi Sektor Paling Hasilkan Devisa. 
Retrieved September 12, 2019, from https://travel.kompas.com/read/2019/03/23/084500627/bi--industripariwisata-jadi-sektor-paling-hasilkan-devisa

Haryani, P., \& Triyono, J. (2017). Augmented reality (Ar) Sebagai Teknologi Interaktif Dalam Pengenalan Benda Cagar Budaya Kepada Masyarakat. Simetris: Jurnal Teknik Mesin, Elektro Dan IImu Komputer, 8(2), 807. https://doi.org/10.24176/simet.v8i2.1614

Kusumawanto, A., \& Astuti, Z. B. (2018). Arsitektur Hijau Dalam Inovasi Kota. Yogyakarta: UGM Press.

Lamas, D., \& Pender, H.-L. (2013). Foundations of Human-Computer Interaction. Retrieved from https://foundationsofhci.wordpress.com/

Martono, kurniawan T. (2011). Augmented reality sebagai Metafora Baru dalam Teknologi Interaksi Manusia dan Komputer. Jurnal Sistem Komputer, 1(2), 60-64. https://doi.org/10.14710/JSK.V1I2.13

Marzuki, I. W. (2017). PELESTARIAN DAN PENGELOLAAN GEREJA BLENDUK SEMARANG. Jurnal Penelitian Arkeologi Papua Dan Papua Barat, 3(1), 11-21.

Mufti, A. (2015). Rancangan Layar Sebagai Alat Bantu Pendewasa. Faktor Exacta, $8(2), 181-185$.

Santoso, I. (2009). Interaksi Manusia dan Komputer Edisi 2 (2nd ed.). Yogyakarta: Penerbit Andi.

Speicher, M., Zenner, A., \& Degraen, D. (2018). Making Virtual and Augmented reality great again. Retrieved from https://umtl.cs.unisaarland.de/teaching/winter-2017-2018/making-mixed-reality-greatagain.html

Utama, I. G. B. R. (2017). Pemasaran Pariwisata. Yogyakarta: Penerbit Andi.

Utama, I. G. B. R., \& SE, M. A. (2015). Pengantar Industri Pariwisata. Yogyakarta: Deepublish. 